\title{
Pseudonocardia babensis sp. nov., isolated from plant litter
}

\author{
Correspondence \\ Yayoi Sakiyama \\ sakiyama-yayoi@nite.go.jp
}

\author{
Yayoi Sakiyama, ${ }^{1}$ Nguyen K. N. Thao, ${ }^{2}$ Hoang V. Vinh, ${ }^{2}$ Nguyen M. Giang, ${ }^{2}$ \\ Shinji Miyadoh, ${ }^{1}$ Duong V. Hop ${ }^{2}$ and Katsuhiko Ando ${ }^{1}$
}
${ }^{1}$ NITE Biological Resource Center (NBRC), National Institute of Technology and Evaluation (NITE), Kazusakamatari 2-5-8, Kisarazu, Chiba, 292-0818, Japan
${ }^{2}$ Institute of Microbiology and Biotechnology (IMBT), Vietnam National University, Hanoi (VNUH), Japan

\begin{abstract}
A novel actinomycete, designated strain $\mathrm{VN} 05 \mathrm{~A} 0561^{\top}$, was isolated from plant litter collected at $\mathrm{Ba} \mathrm{Be}$ National Park, Vietnam. The substrate mycelia and spore chains fragmented in a manner similar to nocardioform actinomycetes; the spores had smooth surfaces and were rodshaped. Strain VN05A0561 ${ }^{\top}$ had the following chemotaxonomic characteristics: mesodiaminopimelic acid in the cell-wall peptidoglycan, arabinose and galactose as characteristic sugars, MK-8( $\left.\mathrm{H}_{4}\right)$ as the major isoprenoid quinone, phosphatidylcholine as the diagnostic phospholipid and iso- $\mathrm{C}_{16: 0}$ as the major cellular fatty acid. Strain VN05A0561 ${ }^{\top}$ shared low levels of $16 \mathrm{~S}$ rRNA gene sequence similarity $(<97 \%)$ with the type strains of recognized species of the genus Pseudonocardia and could be differentiated from its closest phylogenetic relatives based on phenotypic characteristics. These results suggested that strain VN05A0561 ${ }^{\top}$ represents a novel species of the genus Pseudonocardia, for which the name Pseudonocardia babensis sp. nov. is proposed. The type strain is VN05A0561 ${ }^{\top}$ (=VTCC-A$1757^{\top}=$ NBRC $105793^{\top}$ ).
\end{abstract}

The genus Pseudonocardia was established as a nocardioform actinomycete by Henssen (1957), and its description has been emended based on both chemotaxonomic and morphological variations (Reichert et al., 1998; Huang et al., 2002; Park et al., 2008). On the basis of the lack of mycolic acids and the presence of cell-wall type IV, the genera Amycolata (Lechevalier et al., 1986) and Pseudoamycolata (Akimov et al., 1989) were also proposed as nocardioform actinomycetes. However, the latter two genera were found to have chemotaxonomic properties similar to those of the genus Pseudonocardia (Kothe et al., 1989; Takeuchi et al., 1992), and were incorporated in the genus Pseudonocardia on the basis of 16S rRNA gene sequence analysis (Warwick et al., 1994; McVeigh et al., 1994). Subsequently, members of the genus Actinobispora (Jiang et al., 1991) were also transferred to the genus Pseudonocardia based on identification with the use of specific PCR primers, and re-analysis of 16S rRNA gene sequences and menaquinones of the type species (Huang et al., 2002).

At the time of writing, the genus Pseudonocardia comprises 30 recognized species. Strains of this genus have been isolated from various environmental samples, such as active sludge soil, including those polluted by industrial chemicals

The GenBank/EMBL/DDBJ accession number for the 16S rRNA gene sequence of strain $\mathrm{VNO5A0561^{ \top }}$ is AB514449.
(Lee et al., 2004; Kämpfer \& Kroppenstedt, 2004; Mahendra \& Alvarez-Cohen, 2005; Liu et al., 2006; Kämpfer et al., 2006; Park et al., 2008) and plant samples, including stems, leaves, root nodules, tree-bark compost and a traditional Chinese medicinal plant (Evtushenko et al., 1989; Reichert et al., 1998; Gu et al., 2006; Chen et al., 2009).

In the present study, a Pseudonocardia-like strain isolated from a plant litter sample collected during the course of a study on the diversity of actinomycetes inhabiting Vietnam (Sakiyama et al., 2009) was studied by using a polyphasic taxonomic approach.

Plant litter samples were collected at the Ba Be National Park, Bac Kan, in the mountainous area of northern Vietnam. Samples were dried at room temperature for 5-7 days and subsequently used for isolation. Rehydration and centrifugation methods (Hayakawa et al., 2000) were employed for isolation by using humic acid-vitamin agar (Hayakawa \& Nonomura, 1987) containing nalidixic acid $\left(20 \mathrm{mg} \mathrm{l}^{-1}\right)$ and kabicidine $\left(0.75 \mathrm{mg} \mathrm{l}^{-1}\right)$. Strain VN05A0561 ${ }^{\mathrm{T}}$ was isolated after incubation for more than 10 days at room temperature.

Strain VN05A0561 ${ }^{\mathrm{T}}$ was cultured on yeast extract-soluble starch medium (YS medium; per litre distilled water: $2 \mathrm{~g}$ yeast extract, $10 \mathrm{~g}$ soluble starch and $15 \mathrm{~g}$ agar; $\mathrm{pH} 7.3$ ) at $28{ }^{\circ} \mathrm{C}$ for $10-14$ days. Pale yellow colonies with white aerial 
mycelia appeared on the YS medium. The substrate mycelia of the strain fragmented as per those of a nocardioform actinomycete. The spore chains sometimes formed zig-zagshaped and intercalary swellings. The spores were rodshaped (width, $0.3-0.5 \mu \mathrm{m}$; length, $1.0-2.0 \mu \mathrm{m}$ ) with a smooth surface (Fig. 1). Spores were non-motile. The cultural characteristics of strain VN05A0561 ${ }^{\mathrm{T}}$ were observed on ISP media 2-7 (Shirling \& Gottlieb, 1966) and YS medium at $28{ }^{\circ} \mathrm{C}$ for 3 weeks. Moderate growth was observed on ISP 2-7 and YS medium. Raised and wrinkled colonies with moderate yellow colour appeared on ISP 2, 6 and 7. White aerial mycelia developed on ISP 2 and YS medium.

For chemotaxonomic analysis, biomass of strain VN05A0561 ${ }^{\mathrm{T}}$ was obtained by centrifugation and lyophilization after incubation in yeast extract-glucose broth (per litre distilled water: $10 \mathrm{~g}$ yeast extract and $10 \mathrm{~g}$ glucose; $\mathrm{pH}$ 7.3) for 10 days at $28{ }^{\circ} \mathrm{C}$. Diaminopimelic acids and whole-cell sugars were analysed according to the method described by Staneck \& Roberts (1974), isoprenoid quinones and phospholipids according to Minnikin et al. (1984), and cellular fatty acids according to Tamura et al. (1994) and by using the MIDI Sherlock Microbial Identification system (Microbial ID). Strain VN05A0561 ${ }^{\mathrm{T}}$ had mesodiaminopimelic acid as the diagnostic diamino acid in the cell-wall peptidoglycan, and arabinose and galactose as characteristic sugars. The cell wall was of type IV (Lechevalier \& Lechevalier, 1970). The major isoprenoid quinone was MK-8 $\left(\mathrm{H}_{4}\right)$. The cellular fatty acid profile of strain VN05A0561 ${ }^{\mathrm{T}}$ contained iso- $\mathrm{C}_{15: 0}(7.9 \%)$, iso$\mathrm{C}_{16: 1} \mathrm{H}(10.5 \%)$, iso- $\mathrm{C}_{16: 0}(54.4 \%)$ and anteiso- $\mathrm{C}_{17: 0}$ $(14.1 \%)$ as major components, with minor amounts of iso- $\mathrm{C}_{14: 0}(3.4 \%)$, anteiso- $\mathrm{C}_{15: 0}(1.3 \%), \mathrm{C}_{15: 1} \mathrm{~B}(1.7 \%)$, $\mathrm{C}_{16: 0}$ 9? methyl (1.8\%), iso- $\mathrm{C}_{17: 0}(1.3 \%)$ and anteiso$\mathrm{C}_{17: 0}(3.7 \%)$. The phospholipid was of type PIII, and the polar lipid profile consisted of phosphatidyl- $N$-methylethanolamine, phosphatidylcholine, diphosphatidylglycerol, phosphatidylinositol and three unknown glycolipids. The chemotaxonomic properties of strain $\mathrm{VN} 05 \mathrm{~A} 0561^{\mathrm{T}}$ were consistent with the characteristics described for the genus Pseudonocardia.

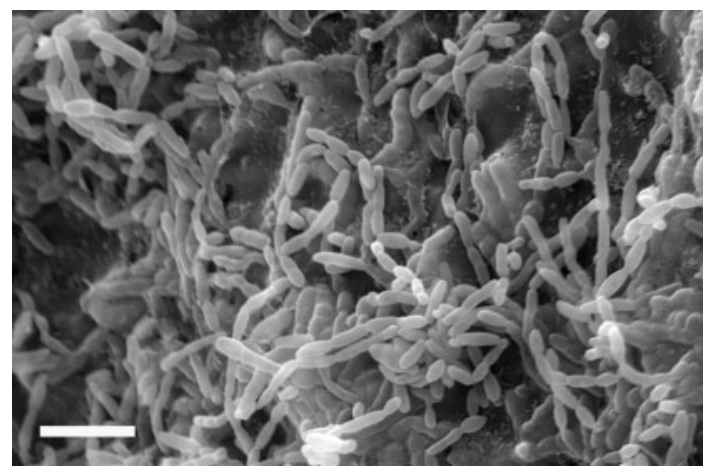

Fig. 1. Scanning electron micrograph of cells of strain VN05A0561 ${ }^{\top}$ grown on ISP 2 medium for 14 days at $28^{\circ} \mathrm{C}$. Bar, $5 \mu \mathrm{m}$.
For 16S rRNA gene sequence analysis, the DNA of strain VN05A0561 ${ }^{\mathrm{T}}$ was extracted and amplified by using the procedures described by Sakiyama et al. (2009). The $16 \mathrm{~S}$ rRNA gene sequence of strain VN05A0561 ${ }^{\mathrm{T}}$ was aligned via the CLUSTAL_X program (Thompson et al., 1997) by using the corresponding sequences of the type strains of all recognized species of the genus Pseudonocardia available in the DDBJ/ EMBL/GenBank databases. Phylogenetic trees were constructed by using the neighbour-joining (Saitou \& Nei, 1987), maximum-parsimony (Kluge \& Farris, 1969) and maximum-likelihood (Felsenstein, 1981) methods. The topology of the phylogenetic trees was evaluated by bootstrap analysis of 1000 replicates (Felsenstein, 1985). The DNA G + C content of strain VN05A0561 ${ }^{\mathrm{T}}$ was determined by using the method described by Mesbah et al. (1989).

The 16S rRNA gene sequence of strain VN05A0561 ${ }^{\mathrm{T}}$ determined herein was $1454 \mathrm{nt}$ long and showed 93.9$96.9 \%$ nucleotide sequence similarity with those of the type strains of all recognized species of the genus Pseudonocardia. Strain VN05A0561 ${ }^{\mathrm{T}}$ was most closely related to the type strains of Pseudonocardia xinjiangensis (96.9\% 16S rRNA gene sequence similarity), Pseudonocardia chloroethenivorans, Pseudonocardia hydrocarbonoxydans, Pseudonocardia alaniniphila, Pseudonocardia aurantiaca (all 96.6\%) and Pseudonocardia asaccharolytica (96.4\%). Phylogenetic analysis based on $16 \mathrm{~S}$ rRNA gene sequences showed that strain VN05A0561 ${ }^{\mathrm{T}}$ formed a cluster with the type strains of $P$. asaccharolytica and Pseudonocardia acaciae (Fig. 2), but did not form any definite clusters with other closely related Pseudonocardia strains. 16S rRNA gene sequence analysis thus suggested that strain VN05A0561 ${ }^{\mathrm{T}}$ represents a novel species of the genus Pseudonocardia (Stackebrandt \& Goebel, 1994; Stackebrandt \& Ebers, 2006). The DNA G + C content of strain VN05A0561 ${ }^{\mathrm{T}}$ was $73 \mathrm{~mol} \%$.

The physiological and biochemical characteristics of strain VN05A0561 ${ }^{\mathrm{T}}$ were examined after incubation at $28{ }^{\circ} \mathrm{C}$ for 3 weeks. YS medium containing $0,1,2,3,4$ and $5 \% \mathrm{NaCl}$ $(\mathrm{w} / \mathrm{v})$ was used for tests of $\mathrm{NaCl}$ tolerance. Urease production, degradation of casein and other compounds, utilization of citrate, other organic acids and carbohydrates, and acid production from carbohydrates were examined according to the methods of Sakiyama et al. (2009).

Strain VN05A0561 ${ }^{\mathrm{T}}$ could be differentiated from $P$. xinjiangensis based on $\mathrm{NaCl}$ tolerance, urease production, hypoxanthine decomposition and acid production from Dsorbitol and adonitol (Table 1).

On the basis of data from the present taxonomic study, we suggest that strain VN05A0561 ${ }^{\mathrm{T}}$ represents a novel species of the genus Pseudonocardia, for which the name Pseudonocardia babensis sp. nov. is proposed.

\section{Description of Pseudonocardia babensis sp. nov.}

Pseudonocardia babensis (ba.ben'sis. N.L. fem. adj. babensis referring to Ba Be National Park, Vietnam, from where the type strain was isolated). 


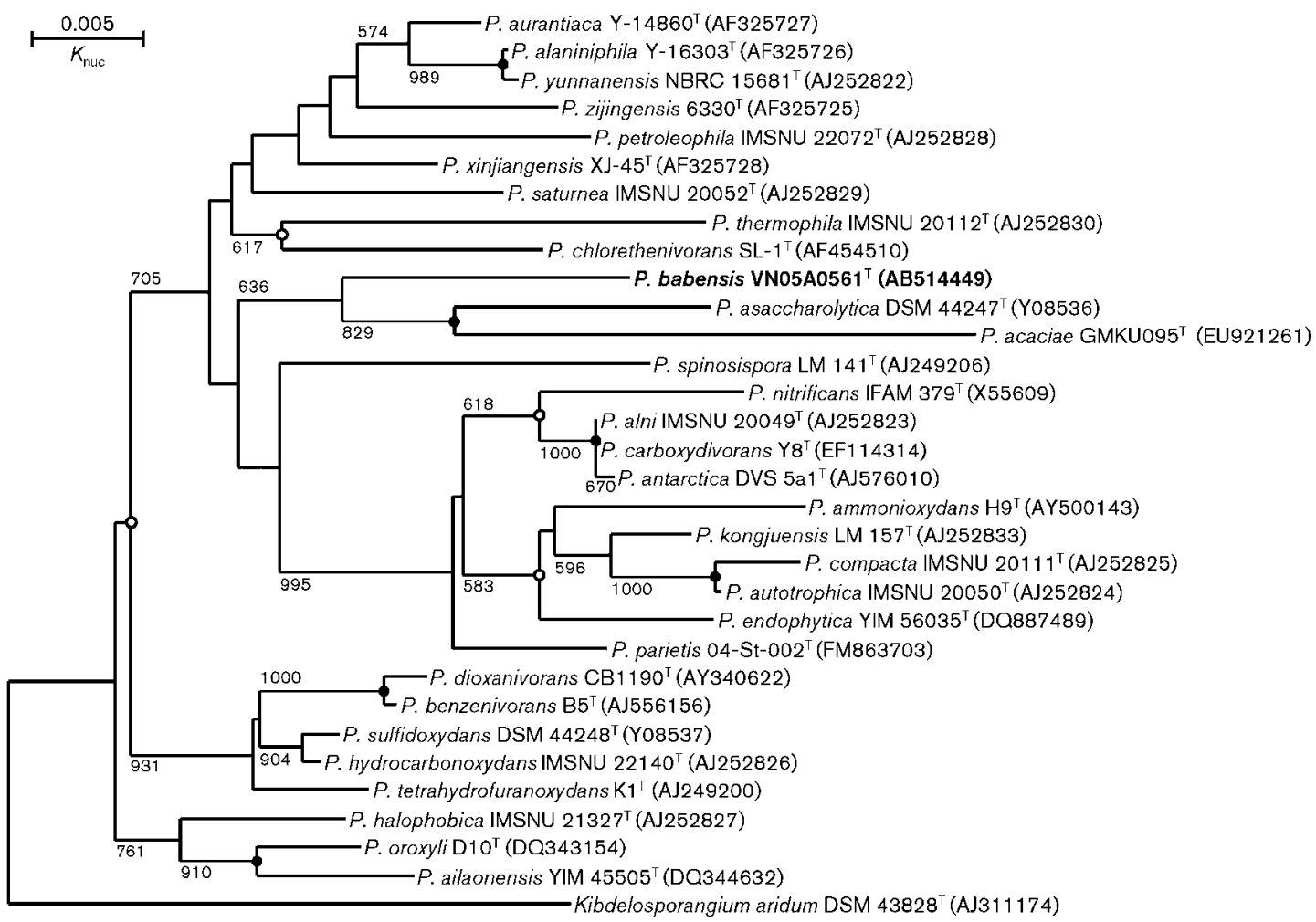

Fig. 2. Neighbour-joining phylogenetic tree reconstructed based on $16 \mathrm{~S}$ rRNA gene sequences showing the position of strain VN05A0561 ${ }^{\top}$ among members of the genus Pseudonocardia. Numbers on branches are confidence limits estimated by bootstrap analysis of 1000 replicates (only values above 500 are presented). Closed circles indicate branches that were also recovered with both the maximum-parsimony and the maximum-likelihood method; open circles indicate branches that were also recovered with the maximum-likelihood method. Bar, 0.005 sequence divergence $\left(K_{\text {nuc }}\right)$.

Aerobic, Gram-positive, non-motile actinomycete. Colonies on YS medium are pale yellow and on ISP media 2, 6 and 7 are moderate yellow. Substrate mycelium frag-

Table 1. Differential physiological and biochemical characteristics between strain VN05A0561 ${ }^{\top}$ and closely related species of the genus Pseudonocardia

Taxa: 1, strain VN05A0561 ${ }^{\mathrm{T}} ; 2$, P. xinjiangensis CCTCC AA97020 ${ }^{\mathrm{T}}$; 3 , P. chloroethenivorans $\mathrm{SL}-1^{\mathrm{T}} ; 4, P$. hydrocarbonoxydans DSM $43281^{\mathrm{T}}$; 5, P. alaniniphila CCTCC AA97001 ${ }^{\mathrm{T}} ; 6$, P. aurantiaca CCTCC AA97002 $2^{\mathrm{T}}$; 7, P. asaccharolytica; 8, P. acaciae GMKU $095^{\mathrm{T}}$. Data for reference strains were taken from Lee et al. (2004) and Duangmal et al. (2009). +, Positive; -, negative; w, weakly positive; ND, no data.

\begin{tabular}{|c|c|c|c|c|c|c|c|c|}
\hline Characteristic & 1 & 2 & 3 & 4 & 5 & 6 & 7 & 8 \\
\hline \multicolumn{9}{|l|}{ Acid production from: } \\
\hline D-Sorbitol & + & - & - & - & - & - & - & - \\
\hline Adonitol & - & + & - & - & - & - & - & + \\
\hline \multicolumn{9}{|l|}{ Decomposition of: } \\
\hline Urea & - & + & - & - & - & + & - & + \\
\hline Hypoxanthine & - & + & + & - & + & + & - & ND \\
\hline Growth on $3 \%(w / v) ~ N a C l$ & + & - & $\mathrm{w}$ & - & - & - & - & + \\
\hline
\end{tabular}

ments. White aerial mycelia and rod-shaped spores (width, 0.3-0.5 $\mu \mathrm{m}$; length, 1.0-2.0 $\mu \mathrm{m}$ ) with a smooth surface form on ISP 2 and YS medium. Grows at $10-45{ }^{\circ} \mathrm{C}$ and in the presence of $0-3 \%(\mathrm{w} / \mathrm{v}) \mathrm{NaCl}$. Decomposes aesculin, casein and testosterone, but not adenine, hypoxanthine, xanthine, L-tyrosine or urea. Utilizes carbohydrates such as L-arabinose, D-arabitol, cellobiose, dulcitol, D-fructose, Dgalactose, D-glucose, myo-inositol, lactose, maltose, Dmannitol, melezitose, melibiose, methyl $\alpha$-D-glucoside, raffinose, L-rhamnose, salicin, D-sorbitol, L-sorbose, starch, sucrose, trehalose, xylitol and D-xylose, but not adonitol. Utilizes organic acids such as fumarate, malate and succinate, but not benzoate, mucate, oxalate, or L-tartrate. Produces acid from L-arabinose, cellobiose, D-fructose, Dgalactose, D-glucose, melezitose, D-sorbitol, sucrose and Dxylose, but not from adonitol or i-erythritol . The cell-wall diamino acid is meso-diaminopimelic acid. Whole-cell sugars are arabinose, mannose, glucose and galactose. The major menaquinone is $\mathrm{MK}-8\left(\mathrm{H}_{4}\right)$. Major fatty acids are iso- $\mathrm{C}_{16: 0}$, iso- $\mathrm{C}_{16: 1}$ and anteiso- $\mathrm{C}_{17: 0}$. Phospholipids are phosphatidyl- $N$-methylethanolamine, phosphatidylcholine, diphosphatidylglycerol, phosphatidylinositol and three unknown glycolipids. The DNA G $+\mathrm{C}$ content of the type strain is $73 \mathrm{~mol} \%$. 
The type strain, VN05A0561 ${ }^{\mathrm{T}}\left(=\mathrm{VTCC}-\mathrm{A}-1757^{\mathrm{T}}=\mathrm{NBRC}\right.$ $105793^{\mathrm{T}}$ ), was isolated from plant litter collected in Vietnam.

\section{Acknowledgements}

This work was conducted as a joint research project between the Department of Biotechnology, National Institute of Technology and Evaluation, Japan, and the Institute of Microbiology and Biotechnology (IMBT), Vietnam National University, Hanoi. We are grateful to Dr Tomohiko Tamura, Ms Kozue Anzai, Mr Nobuyuki Goto, Dr Misa Otoguro, Mr Shinpei Ino, Ms Ayako Hashimoto and all IMBT members for their technical help and advice.

\section{References}

Akimov, V. N., Evtushenko, L. I. \& Dobritsa, S. V. (1989). Pseudoamycolata halophobica gen. nov., sp. nov. Int J Syst Bacteriol 39, 457-461.

Chen, H. H., Qin, S., Li, J., Zhang, Y. Q., Xu, L. H., Jiang, C. L., Kim, C. J. \& Li, W. J. (2009). Pseudonocardia endophytica sp. nov., isolated from the pharmaceutical plant Lobelia clavata. Int J Syst Evol Microbiol 59, 559-563.

Duangmal, K., Thamchaipenet, A., Matsumoto, A. \& Takahashi, Y. (2009). Pseudonocardia acaciae sp. nov., isolated from roots of Acacia auriculiformis A. Cunn. ex Benth. Int J Syst Evol Microbiol 59, 14871491.

Evtushenko, L. I., Akimov, V. N., Dobritsa, S. V. \& Taptykova, S. D. (1989). A new species of actinomycete, Amycolata alni. Int J Syst Bacteriol 39, 72-77.

Felsenstein, J. (1981). Evolutionary trees from DNA sequences: a maximum likelihood approach. J Mol Evol 17, 368-376.

Felsenstein, J. (1985). Confidence limits on phylogenies: an approach using the bootstrap. Evolution 39, 783-791.

Gu, Q., Luo, H., Zheng, W., Liu, Z. \& Huang, Y. (2006). Pseudonocardia oroxyli sp. nov., a novel actinomycete isolated from surface-sterilized Oroxylum indicum root. Int J Syst Evol Microbiol 56, 2193-2197.

Hayakawa, M. \& Nonomura, H. (1987). Humic acid-vitamin agar, a new medium for selective isolation of soil actinomycetes. J Ferment Technol 65, 501-509.

Hayakawa, M., Otoguro, M., Takeuchi, T., Yamazaki, T. \& linuma, Y. (2000). Application of a method incorporating differential centrifugation for selective isolation of motile actinomycetes in soil and plant litter. Antonie van Leeuwenhoek 78, 171-185.

Henssen, A. (1957). Beiträge zur Morphologie und Systematik der thermophilen Actinomyceten. Arch Mikrobiol 26, 373-414.

Huang, Y., Wang, L., Lu, Z., Hong, L., Liu, Z., Tan, G. Y. A. \& Goodfellow, M. (2002). Proposal to combine the genera Actinobispora and Pseudonocardia in an emended genus Pseudonocardia, and description of Pseudonocardia zijingensis sp. nov. Int $J$ Syst Evol Microbiol 52, 977-982.

Jiang, C., Xu, L., Yang, Y.-R., Guo, G.-Y., Ma, J. \& Liu, Y. (1991). Actinobispora, a new genus of the order Actinomycetales. Int J Syst Bacteriol 41, 526-558.

Kämpfer, P. \& Kroppenstedt, R. M. (2004). Pseudonocardia benzenivorans sp. nov. Int J Syst Evol Microbiol 54, 749-751.

Kämpfer, P., Kohlweyer, U., Thiemer, B. \& Andreesen, J. R. (2006). Pseudonocardia tetrahydrofuranoxydans sp. nov. Int J Syst Evol Microbiol 56, 1535-1538.

Kluge, A. G. \& Farris, J. S. (1969). Quantitative phyletics and the evolution of anurans. Syst Zool 18, 1-32.
Kothe, H. W., Vobis, G., Kroppenstedt, R. M. \& Henssen, A. (1989). A taxonomic study of mycolateless, wall chemotype IV actinomycetes. Syst Appl Microbiol 12, 61-69.

Lechevalier, M. P. \& Lechevalier, H. A. (1970). Chemical composition as a criterion in the classification of aerobic actinomycetes. Int J Syst Bacteriol 20, 435-443.

Lechevalier, M. P., Prauser, H., Labeda, D. P. \& Ruan, J. S. (1986). Two new genera of nocardioform actinomycetes: Amycolata gen. nov. and Amycolatopsis gen. nov. Int J Syst Bacteriol 36, 29-37.

Lee, S. B., Strand, S. E., Stensel, H. D. \& Herwig, R. P. (2004). Pseudonocardia chloroethenivorans sp. nov., a chloroethene-degrading actinomycete. Int J Syst Evol Microbiol 54, 131-139.

Liu, Z. P., Wu, J. F., Liu, Z. H. \& Liu, S. J. (2006). Pseudonocardia ammonioxydans sp. nov., isolated from coastal sediment. Int J Syst Evol Microbiol 56, 555-558.

Mahendra, S. \& Alvarez-Cohen, L. (2005). Pseudonocardia dioxanivorans sp. nov., a novel actinomycete that grows on 1,4-dioxane. Int $J$ Syst Evol Microbiol 55, 593-598.

McVeigh, H. P., Munro, J. \& Embley, T. M. (1994). The phylogenetic position of Pseudoamycolata halophobica (Akimov et al. 1989) and a proposal to reclassify it as Pseudonocardia halophobica. Int J Syst Bacteriol 44, 300-302.

Mesbah, M., Premachandran, U. \& Whitman, W. B. (1989). Precise measurement of the $\mathrm{G}+\mathrm{C}$ content of deoxyribonucleic acid by highperformance liquid chromatography. Int J Syst Bacteriol 39, 159-167.

Minnikin, D. E., O'Donnell, A. G., Goodfellow, M., Alderson, G., Athalye, M., Schaal, A. \& Parlett, J. H. (1984). An integrated procedure for the extraction of bacterial isoprenoid quinones and polar lipids. J Microbiol Methods 2, 233-241.

Park, S. W., Park, S. T., Lee, J. E. \& Kim, Y. M. (2008). Pseudonocardia carboxydivorans sp. nov., a carbon monoxide-oxidizing actinomycete, and an emended description of the genus Pseudonocardia. Int J Syst Evol Microbiol 58, 2475-2478.

Reichert, K., Lipski, A., Pradella, S., Stackebrandt, E. \& Altendorf, K. (1998). Pseudonocardia asaccharolytica sp. nov. and Pseudonocardia sulfidoxydans sp. nov., two new dimethyl disulfide-degrading actinomycetes and emended description of the genus Pseudonocardia. Int J Syst Bacteriol 48, 441-449.

Saitou, N. \& Nei, M. (1987). The neighbor-joining method: a new method for reconstructing phylogenetic trees. Mol Biol Evol 4, 406425.

Sakiyama, Y., Nguyen, K. N. T., Nguyen, M. G., Miyadoh, S., Duong, V. H. \& Ando, K. (2009). Kineosporia babensis sp. nov., isolated from plant litter in Vietnam. Int J Syst Evol Microbiol 59, 550-554.

Shirling, E. B. \& Gottlieb, D. (1966). Methods for characterization of Streptomyces species. Int J Syst Bacteriol 16, 313-340.

Stackebrandt, E. \& Ebers, J. (2006). Taxonomic parameters revisited: tarnished gold standards. Microbiol Today 33, 152-155.

Stackebrandt, E. \& Goebel, B. M. (1994). Taxonomic note: a place for DNA-DNA reassociation and $16 \mathrm{~S}$ rRNA sequence analysis in the present species definition in bacteriology. Int J Syst Bacteriol 44, 846849.

Staneck, J. L. \& Roberts, G. D. (1974). Simplified approach to identification of aerobic actinomycetes by thin-layer chromatography. Appl Microbiol 28, 226-231.

Takeuchi, M., Nishii, T. \& Yokota, A. (1992). Taxonomic significance of arabinose in the family Pseudonocardiaceae. Actinomycetologica 6, 79-90.

Tamura, T., Nakagaito, Y., Nishii, T., Hasegawa, T., Stackebrandt, E. \& Yokota, A. (1994). A new genus of the order Actinomycetales, Couchioplanes gen. nov., with descriptions of Couchioplanes caeruleus 
(Horan and Brodsky 1986) comb. nov. and Couchioplanes caeruleus subsp. azureus subsp. nov. Int J Syst Bacteriol 44, 193-203.

Thompson, J. D., Gibson, T. J., Plewniak, F., Jeanmougin, F. \& Higgins, D. G. (1997). The CLUSTAL_X windows interface: flexible strategies for multiple sequence alignment aided by quality analysis tools. Nucleic Acids Res 25, 4876-4882.
Warwick, S., Bowen, T., McVeigh, H. \& Embley, T. M. (1994). A phylogenetic analysis of the family Pseudonocardiaceae and the genera Actinokineospora and Saccharothrix with 16S rRNA sequences and a proposal to combine the genera Amycolata and Pseudonocardia in an emended genus Pseudonocardia. Int J Syst Bacteriol 44, 293299. 